\title{
O que pensam e dizem os alunos
}

Fica atento ... O telejornal de hoje vai (pode) abrir com esta notícia "Electrão, uma partícula negativa elementar?... novas descobertas mais à frente..." Imagina 0 resto e conta a história.... Em prosa ou poesia.

Este foi um desafio colocado a uma turma de alunos do 9. ${ }^{\circ}$ ano. Cinco dos alunos redigiram textos que se trans- crevem a seguir, total ou parcialmente, conforme foram divulgados na escola. Entendo que se queremos saber melhor o que dizem e como, o que sabem e/ou pensam que sabem os nossos alunos, nada melhor que os colocar a falar sobre... isso mesmo! Depois de os escutar poderemos descobrir novas formas de aprender e ensinar...

\section{Electrão, partícula elementar ????}

\section{Poema do electrão}

Electrão, uma partícula negativa elementar,

concerteza que é,

e sempre será,

uma fonte de energia a descarregar,

electrão, um nome tão chamado,

mas tão pouco utilizado,

uma partícula negativa,

que agora canta até o fado,

O०० grande electrão...

Porque me fazes isto a mim?

Eu que sou o único que te compreende

O único a criar coisas sem fim...

O electrão, até agora uma partícula elementar, deixou de o ser.

Esta autêntica revolução Física, que vai alterar inúmeras leis decretadas unanimemente pela comunidade científica, foi comandada por uma equipa de físicos portugueses.

A divisão do electrão foi conseguida quando se fizeram chocar duas destas partículas, num ambiente fechado, à velocidade da luz (300 $000 \mathrm{~km} / \mathrm{s}$ ), originando o elektren, nome dado à parte mais pequena do electrão. As experiências vão ser repetidas....

André Arrojado

* Escola Secundária Prof. Reynaldo dos Santos,

Vila Franca de Xira
Um grupo de cientistas conseguiu dividir um electrão, o que até agora se considerava impossível. Uma grande descoberta que irá mudar a maneira como os cientistas encaram a Química, e não só. A divisão desta partícula negativa só aconteceu com a ajuda de engenhos "topo de gama" que chegaram a custar 50000 a 100000 Euros... Fiquei estupefacto com a notícia deste incrível acontecimento...

Jonas Ventura

... Foi hoje feita uma grande descoberta no CERN, Suiça, os investigadores conseguiram dividir o electrão em partículas às quais decidiram, prontamente, chamar Luzitrão. Nascida da palavra Luz, a partícula tem este nome devido à velocidade com que o electrão chocou e se dividiu, $200000 \mathrm{~km} / \mathrm{h}$, parecida com a velocidade da luz.

Tiago Paiva

Ontem, cientistas Norte-Americanos, do estado de Nevada, conseguiram dividir um electrão, partícula que se considerava ser o extremo da divisão dos corpos. Este investimento custou 20 milhões de dólares ao Estado.

Foi uma divisão microscópica mas um avanço gigante na compreensão do mundo e da Química. Sem dúvida que está aberta a porta para novas e diferentes descobertas no ramo das ciências e da tecnologia.

Rafael Rodrigues

Será possível Sr. Jornalista? Ou está a informar-nos que a divisão do electrão não é a única novidade??????

Um espectador atento e curioso 